\title{
Strategies and Approaches Towards Environmental Biomonitoring of Freshwater Ecosystems in Philippines
}

\author{
J. S. Berame*(**)†, M. B. Hojilla*(***), E. Trinidad*(****), N. L. Lawsin*(*****), J. A. Orozco*(******), \\ I. J. Arevalo*(*******) and Zeba F. Alam* \\ *De La Salle University, Manila, Philippines \\ **Caraga State University, Butuan City, Philippines \\ ***West Visayas State University, Iloilo City, Philippines \\ ****O Our Lady of Fatima University, Valenzuela City, Philippines \\ ***** Pamantasan ng Lungsod ng Muntinlupa, Muntinlupa City, Philippines \\ ******Philippine Normal University, Taft Avenue, Manila, Philippines \\ ********Colegio San Agustin, Laguna, Philippines \\ †Corresponding author: Julie S. Berame; Janveel@yahoo.com
}

Nat. Env. \& Poll. Tech.

Website: www.neptjournal.com

Received: 11-02-2021

Revised: 20-03-2021

Accepted: 14-04-2021

Key Words:

Biomonitoring

Aquatic ecosystems

Heavy metals

Organic pollutants

Bioremediation

\section{ABSTRACT}

The Philippines, like many other Asian countries, is struggling to combat the current widespread aquatic pollution levels caused by anthropogenic activities. Environmental biomonitoring is an efficient tool to detect and monitor the fluctuating toxicity levels in a dynamic ecosystem using bioindicators like algae, macrophytes, zooplankton, insect, bivalve mollusks, gastropod, fish, amphibians, and others to assess the extent and levels of pollution in aquatic ecosystems. The present review deliberates on the biomonitoring techniques such as bioaccumulation, biochemical alterations, population, and community-level approaches to evaluate the current status with respect to the extent and levels of pollution in the aquatic ecosystems in the Philippines which also is one of the biodiversity hotspots. Therefore, the potential applications for biomonitoring are proposed to mainly include evaluation of actual aquatic pollutions, bioremediation, toxicology prediction, and research on toxicological mechanisms. The purpose of such evaluations is to critically analyze and help stakeholders to come up with a strategic action plan with recommendations on a low-cost, sensitive, and effective bioindicator for rapid and efficient environmental biomonitoring.

\section{INTRODUCTION}

The Philippines with 7,641 islands is endowed with 421 principal rivers with 18 major river basins, and 79 natural lakes, which constitutes the freshwater ecosystem (EMB 2013). The Philippine archipelago has a coastline of $36,289 \mathrm{~km}$ which is the sixth longest coastline in the world, with the West Philippine Sea on the western side, the Philippine Sea on the east, and the Celebes Sea on the south (World Atlas 2020). There are 18 major river basins with the Cagayan River being the largest with a catchment area of $25,649 \mathrm{~km}^{2}$ (DPWH, 2004). Both the freshwater as well as marine water ecosystems are at threat due to numerous anthropogenic activities such as urbanization, overexploitation of the natural resources, and more leading to the loss of aquatic biodiversity (PEMSEA 2016). These human activities can lead to physicochemical and biological changes in an ecosystem which should be identified accurately, rapidly, and before major destruction can occur to the ecosystem (Hughes et al. 2004).
In the Philippines, more attention has been drawn to the wide occurrence of heavy metal pollution in the aquatic environment due to mining activities, cyanide, and many illegal uses of harmful chemicals in the country. These heavy metals may transform into permanent metallic compounds with high toxicity levels of metals like mercury and cyanide levels in the water, which can bioaccumulate in the aquatic plants, organisms' vital organs, and get magnified in the food chain, thus threatening human health as well (Jin et al. 2004). The observed effects such as abnormal development of fetus, procreation failure, and immunodeficiency have been exhibited due to aquatic heavy metal exposure and are a serious threat in the country particularly in Luzon and Mindanao where big mining sites are found (Chang et al. 2009). Hence, monitoring and prevention of heavy metal pollution are one of the hot topics in environmental research, not only in the Philippines but in other progressive countries globally.

Therefore, it is of utmost importance to continuously monitor the ecosystems to identify the source of contam- 
ination, reduce their impact and restore their health status since a healthy ecosystem has the resilience to quickly and completely recover from the risks or threats that generally have detrimental effects on the composition, structure and/ or function of an ecosystem (Fu-Liu \& Shu 2000). The effects of a chemical toxin in a living organism at the level of molecules, organelles, cells, tissues, organs, organisms, populations, communities, ecosystems, and biomes can be assessed through biomonitoring. Over the years, the use of biological monitoring has become more reliable as it provides a complete spectrum of information for proper management of water bodies by integrating, detecting, and using highly diverse flora and fauna to evaluate the health of the aquatic bodies (Li et al. 2010).

In the country, many macro-organisms like fish, macroinvertebrates, macrophytes, protozoa, and others are used for environmental biomonitoring (Marzin et al. 2012). Due to the consistency between the selected organisms and the corresponding living space, biomonitoring can directly provide information on the potential effects and actual cumulative toxicities of pollutants, reflecting the harmful and consistent effect in the environment. The alterations in the physiology, molecules, functions, or number of organisms are the effect indicators whereas the accumulation of materials or toxins from the surroundings can be studied as accumulation bioindicators (Tellez \& Merchant 2015). The stomach contents of fishes like Oncorhynchus mykiss and Salmo trutta and prey diversity can be used to evaluate the pollution levels in the water bodies (Fierro et al. 2015). The bioindicators used in the environmental biomonitoring also give the accumulative changes in an aquatic body over a period of time (Herman $\&$ Nejadhshemi 2015). Hence, the biomonitoring of aquatic bodies can be done by focusing on the bioconcentration or bioaccumulation of toxins/pollutants in aquatic organisms (Deben et al. 2015, García-Seoane et al. 2018), or at the molecular level using biochemical biomarkers such as proteins to understand the molecular responses to contaminants in the living organisms which has led to the new development of a new field of environmental proteomics ( $\mathrm{Li}$ et al. 2018). Thus, this review aims to come up with suggestions on low cost, sensitive, and effective bioindicators that can be used for rapid and efficient biomonitoring of the contaminated freshwater aquatic ecosystems in the country that can help the stakeholders to come up with an effective strategy to monitor the pollution levels in the aquatic bodies.

\section{MATERIALS AND METHODS}

Search strategy: The literature search was conducted based on a thematic technique for systematic reviews and Boolean search methodology for the years 2014-2020 from Google
Scholar, Sci-Hub, and Web of Science. Search terms such as bioassessment, biomonitoring, aquatic ecosystems, and freshwater pollutions, Philippines, etc. were used and from the search results, a total of around 30 publications were selected for the review. The low numbers of relevant publications are indicative of the limited research on environmental biomonitoring conducted in the country.

Inclusion criteria: The data from publications was extracted and information was collected on the study type, pollutants investigated, type of biomarker and matrix, measurement techniques, and quality assurance of the methodology used to carry out the research. Biomonitoring research articles were extensively analyzed and upon further examination, 6 studies were excluded from the present study due to the criteria such as results being reported in earlier studies. The published articles were reviewed, assessed, and ranked independently based on their quality of the study using the criteria such as the specificity of the biomarkers used, the analytical techniques, the quality of the study design, sample handling, and quality assurance.

\section{Data Analysis}

The information and data presented in the research papers included were analyzed, reviewed, and further evaluated by a third abstractor if required.

\section{Techniques and Approaches for Biomonitoring of Aquatic Bodies}

Bioaccumulation: This is an important process where over a period of time an increase in the concentration of a pollutant/chemical in a biological organism may occur compared to the chemical's concentration in the environment. Bioaccumulation occurs when an organism absorbs a toxic substance at a rate greater than that at which the substance is lost. This results from a disturbance to the dynamic equilibrium between exposure from the outside environment and uptake, excretion, storage, and degradation within an organism. Hence often, the bioaccumulation approach is used to monitor heavy metal contamination in the aquatic environment. For organic pollutants, a bivalve, Mya arenaria has been identified as a bioindicator to monitor the tributyltin chloride (TBT) pollution in the marine environment with the Bioconcentration factor $(\mathrm{BCF})$ of $\mathrm{M}$. arenaria ranging from 15538 to 91800 after 28 days of exposure (Zhou \& Guibin 2006). The rapid uptake and low rate of elimination of TBT reactions displayed first-order kinetics.

Biochemical alterations: With the development of biological techniques, research on the interaction between the pollutants and biological macromolecular such as protein, enzyme, and nucleic acid may indicate the action mechanism 
of the pollutants. The alteration in the biological process can be used as a bioindicator to assess the environmental quality hence many biomarkers have currently been developed such as metallothionein, oxidative stress, cyto-toxicological responses such as genotoxicity, lysosomal alterations, immunocompetence, and gencholinesterase activities (Siddig et al. 2016). Some special proteins can be purified to serve as a biomarker for metal exposure as well. Chlorophyll fluorescence, as a potential valuable ecotoxicological endpoint, could be used with a range of aquatic phototrophs for the assessment of aquatic pollution including heavy metals (Ralph et al. 2007). The main advantages are that it is rapid, non-invasive, and non-destructive, while the major weakness is the lack of clear ecological relevance.

Use of Proteomic Analysis: The biomonitoring of the aquatic environment has also been carried out using the proteomic analysis using Annelids (Roohi-Shalmaee et al. 2019); crustaceans (Vellinger 2016), and fishes (Catteau et al. 2021). The impact of oxidative stress on tissues such as muscles, liver, gills, kidneys, brain, or skin, etc has been studied to understand the mechanism (Zhang et al. 2019). The changes in the proteome of goldfish (Carassius auratus) subjected to heat shock and toxins like herbicides and fungicides as a response to cellular stress further confirm that proteomic analysis can be used as a tool for environmental biomonitoring in the aquatic environment (Beese et al. 2012). The Chinese rare minnow (Gobiocypris rarus) exposed to benzotriazole were reported to exhibit alteration in the heat shock proteins and catalase enzyme levels (Liang et al. 2021). The mollusks were also reported to be suitable environmental sentinels with their protein expression strongly affected by the pollutants (Campos et al. 2012).

Population and Community-Level Approaches: Population-level (density, size distribution) and community-level (species richness metrics, multivariate analysis of community composition) responses of the aquatic organisms to pollution in the aquatic ecosystem, are of much significance for the evaluation of the ecological balance induced by water qualities in the studied area. Single or various populations may be involved for different aims. The protozoan communities get affected by heavy metal pollution and can be used for biomonitoring by using the species richness, individual abundance, and biodiversity index as endpoints (Cairns et al. 2009). The response of testate amoebae communities was used as a bioindicator to monitor the heavy metal pollution in the groundwater, stream water, and aquatic bryophytes in the Lanmuchang stream, Guizhou Province, China (Zhang \& He 2010).

\section{Freshwater Ecosystem}

In the Philippines, the Department of Environment and
Natural Resources (DENR) is the government agency responsible for the conservation, management, development, and proper utilization of natural resources. DENR has classified the bodies of freshwater into different categories based on their intended beneficial use (DAO No. 2016-08) (DENR Administrative Order No. 2016-26 2016). This criterion was formulated in 1978 and was revised in 1990 in DAO No. 34. The criterion was further modified in 2016 to support the changing needs of our environment; thus DAO 2016-08 was crafted. Hence, DENR also added the use of the effluent standards to analyze the conditions of the different bodies of water and classify them accordingly (Table 1).

\section{Freshwater Environment}

The National Water Resources Board (NWRB) has identified 18 major river basins, 421 principal rivers and the Bureau of Fisheries and Aquatic Resources (BFAR) of the Department of Agriculture has listed 79 lakes in the Philippines (BFAR 2015). Besides this, an estimated 3.7 million cubic meters of groundwater is extensively used of which $54 \%$ is used for domestic purposes and $25 \%$ for irrigation (DENR 2013). The Department of Environment and Natural Resources (DENR) is the government agency that is responsible for the conservation, management, development, and proper utilization of natural resources including water. To assess the water quality, DENR has taken into account 33 parameters to generally classify the water bodies into different categories based on their intended beneficial use as defined in DAO No, 2016-08 in Table 1. The first criteria were formulated in 1978 and then were revised in 1990 in DAO No. 34 and further modified in 2016 to support the changing needs of the environment. Using these parameters, the water quality of various inland surface water bodies including the 55 principal rivers, 76 minor rivers, and 4 big lakes was monitored (Table 2).

According to the criteria of Dissolved oxygen (DO) used for water quality testing, 59\% of the tested water bodies qualified with "Good" water quality and $29 \%$ with "Fair" water quality in terms of Dissolved oxygen (DO) compliance. However, the main four rivers of the NCR namely-Parañaque River (1.6\%), the Pasig River (4.4\%), Navotas-Malabon-Tullahan-Tinejeros River (7.2\%), and San Juan River (11.5\%) had the lowest DO compliance (Gorme et al. 2010). The discharge of wastewater and other untreated waste causes low DO levels in the aquatic bodies making it difficult for the aquatic organisms to survive as they require at least 5 milligrams per liter $\left(\mathrm{mg}^{\mathrm{L}} \mathrm{L}^{-1}\right)$ of dissolved oxygen. In terms of BOD, the higher the BOD value, the greater is the degree of pollution where most aquatic organisms perish if the BOD level is above $7 \mathrm{mg} . \mathrm{L}^{-1} .57 \%$ of the water bodies 
Table 1: Effluent standards for the classification of water bodies (DENR 2013).

\begin{tabular}{|c|c|c|c|c|c|c|c|c|c|c|}
\hline \multirow[t]{2}{*}{ Parameter } & \multirow[t]{2}{*}{ Unit } & \multicolumn{9}{|c|}{ Water Body Classification } \\
\hline & & AA & A & $\mathrm{B}$ & $\mathrm{C}$ & $\mathrm{D}$ & SA & SB & $\mathrm{SC}$ & SD \\
\hline Ammonia as NH3-N & $\mathrm{mg} / \mathrm{L}$ & NDA & 0.5 & 0.5 & 0.5 & 7.5 & NDA & 0.5 & 0.5 & 7.5 \\
\hline BOD & $\mathrm{mg} / \mathrm{L}$ & NDA & 20 & 30 & 50 & 120 & NDA & 30 & 100 & 150 \\
\hline Boron & $\mathrm{mg} / \mathrm{L}$ & NDA & 2 & 3 & 3 & 12 & NDA & 2 & 20 & 80 \\
\hline Chloride & $\mathrm{mg} / \mathrm{L}$ & NDA & 350 & 350 & 450 & 500 & NDA & $\mathrm{n} / \mathrm{a}$ & $\mathrm{n} / \mathrm{a}$ & $\mathrm{n} / \mathrm{a}$ \\
\hline COD & $\mathrm{mg} / \mathrm{L}$ & NDA & 60 & 60 & 100 & 200 & NDA & 60 & 200 & 300 \\
\hline Color & TCU & $\mathrm{NDA}$ & 100 & 100 & 150 & 300 & NDA & 100 & 150 & 300 \\
\hline Cyanide as Free Cyanide & $\mathrm{mg} / \mathrm{L}$ & NDA & 0.14 & 0.14 & 0.2 & 0.4 & NDA & 0.04 & 0.2 & 0.4 \\
\hline Fluoride & $\mathrm{mg} / \mathrm{L}$ & NDA & 2 & 2 & 2 & 4 & NDA & 3 & 3 & 6 \\
\hline Nitrate as NO3-N & $\mathrm{mg} / \mathrm{L}$ & NDA & 14 & 14 & 14 & 30 & NDA & 20 & 20 & 30 \\
\hline pH (Range) & & NDA & $6.0-9.0$ & $6.0-9.0$ & $6.0-9.5$ & $5.5-9.5$ & NDA & $6.5-9.0$ & $6.0-9.0$ & $5.5-9.5$ \\
\hline Phosphate & $\mathrm{mg} / \mathrm{L}$ & NDA & 1 & 1 & 1 & 10 & NDA & 1 & 1 & 10 \\
\hline Selenium & $\mathrm{mg} / \mathrm{L}$ & NDA & 0.02 & 0.02 & 0.04 & 0.08 & NDA & 0.02 & 0.2 & 0.4 \\
\hline Sulfate & $\mathrm{mg} / \mathrm{L}$ & NDA & 500 & 500 & 550 & 1,000 & NDA & 500 & 550 & 1,000 \\
\hline Surfactants (MBAS) & $\mathrm{mg} / \mathrm{L}$ & NDA & 2 & 3 & 15 & 30 & NDA & 3 & 15 & 30 \\
\hline Temperature (h) & ${ }^{\circ} \mathrm{C}$ change & NDA & 3 & 3 & 3 & 3 & NDA & 3 & 3 & 3 \\
\hline Total Suspended Solids & $\mathrm{mg} / \mathrm{L}$ & NDA & 70 & 85 & 100 & 150 & NDA & 70 & 100 & 150 \\
\hline Arsenic & $\mathrm{mg} / \mathrm{L}$ & $\mathrm{NDA}$ & 0.02 & 0.02 & 0.04 & 0.08 & NDA & 0.02 & 0.04 & 0.08 \\
\hline Barium & $\mathrm{mg} / \mathrm{L}$ & NDA & 1.5 & 1.5 & 6 & 8 & NDA & 1.5 & 2 & 8 \\
\hline Cadmium & $\mathrm{mg} / \mathrm{L}$ & NDA & 0.006 & 0.006 & 0.01 & 0.02 & NDA & 0.006 & 0.01 & 0.02 \\
\hline $\begin{array}{l}\text { Chromium as Hexavalent } \\
\text { Chromium }(\mathrm{Cr} 6+)\end{array}$ & $\mathrm{mg} / \mathrm{L}$ & NDA & 0.02 & 0.02 & 0.02 & 0.04 & NDA & 0.1 & 0.1 & 0.2 \\
\hline
\end{tabular}

met the BOD compliance though most of these water bodies are classified as Class A or Class C. Paranaque River, San Juan, Pasig, and Meycauayan Rivers failed to meet the BOD compliance in most of their sampling events (Gorme et al. 2010) (Table 3).

Table 2: Monitored water quality parameters per type of water body (DENR 2013).

\begin{tabular}{|ll|}
\hline Water Body & Water Quality Parameter \\
\hline Inland surface waters & Dissolved oxygen (DO) \\
& Biochemical oxygen demand (BOD) \\
& Total suspended solids (TSS) \\
& Phosphates \\
& Nitrates \\
& Heavy metals \\
& Cyanide as free cyanide \\
& Fecal coliform \\
Ground Water & Nitrates \\
& Salinity (chloride content) \\
& Fecal coliform \\
Coastal and marine waters & Total coliform \\
& DO \\
\hline
\end{tabular}

Table 4 shows the status of the top 11 largest rivers in the Philippines and its classification based on the Environmental Management Bureau (EMB). Laguna de Bay is the largest freshwater lake in the Philippines and was categorized as class $\mathrm{C}$ with fishery water for the propagation of growth of fish and other aquatic resources, recreational water class II - for boating, fishing, or similar activities, and agriculture, irrigation, and livestock watering.

\section{Sources of Pollution}

The water bodies inside the country as well as that surround the landmass are contaminated and polluted. The prevailing water pollution has greatly affected the lives of the Filipinos. The identified sources of water pollution are- (1) Industrial wastes with heavy metals like lead, mercury, chromium, cadmium, cyanide, and more (Olivares et al. 2019); (2) Agricultural wastes including organic wastes such as decayed plants, dead animals, livestock manure, soil runoff; and non-organic wastes, like pesticides and fertilizers; (3) Domestic sewage that may contain pathogens capable of causing diseases to humans and animals (Olivares et al. 
Table 3: Priority principal rivers subject to regular monitoring in the Philippines (Tuddao \& Gonzales 2016).

\begin{tabular}{|lllll|}
\hline Rivers & Location (Luzon and Mindanao Regions) & Class & DO $\left(\mathrm{mg} . \mathrm{L}^{-1}\right)$ & BOD $\left(\mathrm{mg} . \mathrm{L}^{-1}\right)$ \\
\hline Meycauayan River & Region III & $\mathrm{C}$ & 0.88 & 88.67 \\
Marilao River & Region III & $\mathrm{C}$ & 2.06 & 43.48 \\
Bocaue River & Region III & $\mathrm{C}$ & 2.52 & 27.03 \\
Imus River & Region IVA & $\mathrm{C}$ & $5.09 * *$ & 10.63 \\
Ylang-ylang River & Region IVA & $\mathrm{C}$ & 4.6 & 4.9 \\
Tagbruos River & Region IVB & $\mathrm{C}$ & 4.81 & 9.65 \\
Calapan River & Region IVB & $\mathrm{C}$ & 1.3 & 6.39 \\
Salog River & Region V & $\mathrm{C}$ & 5.81 & 3.55 \\
Balos River & Region V & $\mathrm{C}$ & 7 & 2 \\
Sagumayon River & Region V & $\mathrm{C}$ & 4.11 & 22.16 \\
Balili River & CAR & $\mathrm{A}$ & 5.9 & 59.5 \\
\hline
\end{tabular}

Table 4: Top ten largest lakes and their classification in the Philippines (BFAR 2015).

\begin{tabular}{|lllll|}
\hline Lake & Location (Luzon \& Mindanao Lakes) & Area (ha) & Region & Water Body Classification and Usage of Freshwater \\
\hline Laguna de Bay & Laguna and Rizal & 89,076 & $4-\mathrm{A}$ & C \\
Lake Lanao & Lanao del Sur & 34,000 & 10 & $\mathrm{~A}$ \\
Taal Lake & Batangas & 24,356 & $4-\mathrm{A}$ & $\mathrm{B}$ \\
Lake Mainit & Surigao del Norte-Agusan del Norte & 17,430 & CARAGA & A \\
Agusan Marsh Lake & Agusan del Sur & 14,000 & CARAGA & No Classification \\
Naujan Lake & Oriental Mindoro & 7,899 & $4-\mathrm{B}$ & B \\
Lake Buluan & South Cotabato & 6,134 & 2 & No classification \\
Lake Bato & Camarines Sur & 3,792 & 5 & B \\
Lake Pagusi & Agusan & 2,534 & 8 & No classification \\
Lake Labas & South Cotabato & 2,141 & 7 & No classification \\
Lake Lumao & Agusan & 168 & 8 & No classification \\
\hline
\end{tabular}

2019) and (4) Other sources such as oil, mine or chemical spills and illegal dumping in or near water sources (Andrews 2018).

\section{Kind of Pollutants}

Heavy Metals are inorganic pollutants that pose a negative impact on the environment especially on aquatic organisms, plants, and even humans (Marrone 2016). Heavy metals are indirectly and directly discharged into the environment through mining, agriculture, factories, and commercial wastes. Since heavy metals in their ionic form are soluble in water, they tend to settle down at the sediments and bottom of the rivers where they can accumulate to toxic levels which can harm the aquatic life and humans who consume the fish and other seafood (Vestil \& Lim 2016). Heavy metals such as lead, cadmium, arsenic, and mercury are toxic and may cause harm to organisms (Walag and Canencia, 2018). In terms of total mercury, all monitored rivers were declared safe with mercury levels within the maximum limit of 2 micrograms per liter (ug. $\mathrm{L}^{-1}$ ) with the exception of four rivers, of Agno, Malguit, Panique, and Tubay (Walag et al. 2018). For Cadmium, 8 out of the 18 water bodies tested, were found to be compliant to the maximum limit of $0.01 \mathrm{mg} . \mathrm{L}^{-1}$ and for Lead, 7 out of 18 water bodies met the maximum limit of $0.05 \mathrm{mg} . \mathrm{L}^{-1}$ though it is important to point out that there were concerns that the data has been derived from a very small number of sampling events (Canencia et al. 2016).

Organic Pollutants are organic compounds that can cause toxicity to aquatic plants and animals. One of the most toxic organic pollutants are the endocrine disruptive chemicals (EDCs) which are the external agents that can disrupt the hormonal activities of an organism, thus affecting the homeostatic mechanisms, reproduction, development, or behavior of an organism (Pielou 1998). Furthermore, EDCs can increase the chances of having cancer in humans (Rachon 2016). 


\section{Impact of Freshwater Pollution on Public Health}

Water pollution is considered one of the major environmental problems that the Philippines should prioritize because it can greatly affect the lives of the Filipino people, especially the ones living near the bodies of water. According to the Environmental Management Bureau (EMB), only 47\% out of the Philippines' 127 freshwater bodies retain good water quality which is intended for human usage. The impact of water pollution on the Filipino people living beside the riverbanks was determined based on the following: (a) waterborne viruses and bacteria that contaminate drinking water that can lead to gastrointestinal diseases such as diarrhea, cholera, and various skin diseases; (b) bioaccumulation of toxins that are being built-up over a period of time in the adipose tissues of an organism (Paulaa \& Andow 2016). Water-borne diseases like diarrhea and cholera also account for some diseases associated with polluted water (Andrews \& Gabriella 2018).

Deteriorating water quality also negatively impacts the growth of crops and livestock and overall soil quality, leading to reduced agricultural yields. A decrease in productivity, including smaller crop yield, results in a lower household income and similarly, it can also reduce food supply to man. Furthermore, access to clean water is an important component of preventing malnutrition and decreasing infant mortality. Heavy metals are known to enter the body and can cause nausea/vomiting, diarrhea, kidney and liver failure, cognitive and neuromuscular dysfunction besides genetic alterations resulting in structural defects (Jan et al. 2015).

\section{Impact of Freshwater Pollution in the Environment}

As water pollution puts the health of people at risk, there were direct and indirect effects on the environment such as the eutrophication of lakes. This results in algal blooms, which may lead to the depletion of oxygen available for other freshwater organisms. The depletion of oxygen can cause morphological stress to the other organisms living in these bodies of water, decreasing their overall ability to survive. The draining of fertilizers and pesticides leading to algal bloom and eutrophication, disposal of untreated sewage both from domestic and industrial sources and the deposition of sediment in the riverbeds due to deforestation is the major causes of deterioration in the health of the aquatic ecosystems in the Philippines (Andrews 2018).

\section{Biomarkers Used for Freshwater Environment}

Biomarkers refer to any physiological, biochemical, and histological changes in a living organism that can be used as indicators of exposure to chemical contaminants such as heavy metals and organic compounds (Reboa et al. 2019). Hence, biomarkers are being employed in ecotoxicology to analyze the trends and effects of toxins in an aquatic environment and serve as indicators of exposure to toxicants (Ippolito et al. 2016). Biomarkers in aquatic ecosystems are used to detect environmental stressors and pollutants that may affect environmental conditions such as temperature, $\mathrm{pH}$, oxygen content, and more (Berra et al. 2016). Hence, the development of sensitive biochemical markers is very much needed to detect the conditions of aquatic ecosystems and monitor the status of the environment. The erythrocytes of Nile Tilapia (Oreochromis niloticus) have been used as biomarkers to detect the presence of genotoxic pollutants in Taal Lake, Batangas, where micronucleus test, chromosomal aberration analysis, and comet assay was used to assess the DNA damage in the fish exposed to the genotoxic pollutants in the waters of the Taal Lake (Hallare et al. 2016). The low levels of enzyme- acetylcholinesterase (AChE) in the brain and muscles of white goby using the rapid colorimetric method indicated the exposure to the organophosphates and carbamate pesticides in the Laguna Lake (Fajardo \& Ocampo 2018). The benthic macroinvertebrate assemblages were used for biomonitoring of water quality of the Iligan river (Maagad 2012) and of three Estuary sites in Iligan city (Superada \& Tampus 2015). The water quality of Gibong River in Agusan del Sur was monitored by assessing the diversity of macroinvertebrates (Peligro \& Jumawan 2015).

The biological assemblage such as macroinvertebrates, diatoms, and coliform was used as bioindicators of the status of water quality and habitat degradation of the Cagayan de Oro River (Sinco et al. 2014). Bioaccumulation of heavy metals like $\mathrm{Cu}$ and $\mathrm{Zn}$ was reported in various species of gastropods and bivalves in the estuaries near the mining town in the Camarines Norte region where biomonitoring was conducted over a period of two years (Carino et al. 1993). Riparian Channel and Environmental (RCE) Inventory was done to evaluate the integrity of the riparian vegetation. The presence of lead in the hepatopancreas of the melon conch was used to determine the concentration of lead in Bacoor Bay, Cavite (Sia Su et al. 2015). Hence, the environmental biomonitoring of a freshwater ecosystem can be done using biomarkers though for each area or region a suitable biomarker needs to be identified.

\section{Factors and Sources of Freshwater Pollution}

There is a wide array of factors of marine water pollution in the Philippines. One such factor is the location of the water bodies. Indirectly connected to Manila Bay via the Pasig River is Laguna de Bay, the largest lake in the Philippines. As a semi-enclosed estuary, Manila Bay is surrounded by the highly urbanized National Capital Region (NCR) provinces of Bataan, Pampanga, Bulacan Cavite. Both the Pampanga and Pasig River basins (two main contributory areas) drain their 
waters to Manila Bay. Domestic and agro-industrial wastes, including discharge of municipal wastes, find their way to Manila Bay via these two (Pasig and Pampanga) River Basins.

Metro Manila, considered a megacity, having a population of 10 million or more (UNDESAPD 2018) is one big source of pollution in the water bodies. Metro Manila and some of the other major cities in the Philippines have seen rapid economic growth and development, leading to haphazard urbanization with many environment-related challenges such as an increase in greenhouse gas emissions, rise in solid waste generation, and overall decline in air and water quality (DENR 2013). The agricultural farms in the neighboring provinces surrounding Metro Manila are the source of pesticides that settle down in the sediments of the rivers adversely affecting the benthic dwellers, filter feeders, and the flora/fauna present in the water bodies (Bajet et al. 2010). An increasing number of informal settlers along the Pasig riverbanks contributed to an increase in solid waste generation, clogging the waterways and deterioration in water quality. So much so that Pasig River, once known to have pristine waters is now labeled as the "Toilet Bowl" of Metro Manila (Gorme et al. 2010).

\section{Government Policies on Aquatic Environment}

A number of policies have been put together by the government to prevent the damage and protect the aquatic ecosystems. One of the earliest laws that have been formulated was the Commonwealth Act 383 (1938), which prohibited the dumping of different types of wastes that can cause an elevation or block the course of streams in rivers. Subsequently, Presidential Decrees (PD) such as National Pollution Control Decree (PD 984) was devised to ban the throwing or disposal of any gaseous or liquid pollutants in water, air, and land resources. PD 1067 of 1976 or the Water Code of the Philippines was developed to conserve and regulate the use of water and management of water resources. Furthermore, RA No. 9275 (Clean Water Act) was developed to control wastewater discharges.

\section{CONCLUSION}

In conclusion, biomonitoring provides direct evidence of alterations that occur in the major freshwater ecosystems in the Philippines due to environmental pollution. Integrated information on the water quality can be reflected based on the biomonitoring of aquatic metal pollution, which offers the potential effects and actual toxicities. Notable progress has been achieved due to the biomonitoring efforts with respect to industrial, agricultural, and domestic pollution in aquatic ecosystems in the country. Several biomarkers at the cellular levels have been developed due to the sensitive responses of the organisms that can alert us about the toxic effects induced by current water pollution levels as well as help us to understand the potential toxicological mechanism which can help to undertake precautions and preventions to combat pollution levels. Hence, developing comprehensive monitoring approaches in freshwater ecosystems is very important through constant sampling and testing to monitor the level of toxicity in the aquatic environment, perform a toxicological study on aquatic organisms to determine the extent of the impact on freshwater organisms, determine health risks at individual and group levels through biomonitoring, and conduct an information campaign activities on biomonitoring to educate the members of the local community on the possible occurrence of toxicity induced by pollutants in the aquatic ecosystems.

\section{RECOMMENDATIONS}

The use of mollusks as a bioindicator in biomonitoring is the best way to monitor the aquatic environment. The following actions are recommended for the freshwater environmental biomonitoring: (1) strict implementation of Environmental Laws on biomonitoring in a freshwater environment in the Philippines; (2) develop comprehensive monitoring approaches in the freshwater environment through constant sampling and testing to monitor the level of toxicity in the aquatic environment; (3) perform a toxicological study on aquatic organisms to determine the extent of the impact on freshwater organisms; (4) determine health risks at individual and group levels through biomonitoring, and (5) conduct an information campaign activity on biomonitoring to educate the members of the community on the possible occurrence of poisoning and the importance of biomonitoring in a freshwater environment.

\section{ACKNOWLEDGMENT}

The study was supported by the University Research Coordination Office, De La Salle University, Manila, Philippines, (URCO) grant 77 F U 3TAY18-2TAY20.

\section{REFERENCES}

Alimi, B. 2016. Risk factors in street food practices in developing countries: A review. Fd. Sci. Hum. Wellness, 5(3): 141-148.

Andrews, G. and Gabriella, F. 2018. Resolving the water pollution crisis in the Philippines: The implications of water pollution on public health and the economy. Pepperdine Pol. Rev., 10: 1-15

Bajet, C., Carvalho, F.P., Villeneuve, J., Cattini, C. and NavarroCalingacion, M. 2010. Chlorinated hydrocarbons in sediments from Manila Bay, the Philippines. Inter. J. Environ. Stud., 67(4): 493-504.

Besse, J.P., Geffard, O. and Coquer, M. 2012. Relevance and applicability of active biomonitoring in continental waters under the water framework directive. TrAC Tren. in Analyt. Chem., 36, 113-127

Berra, F., Felletti, F. and Tessarollo, A. 2016. Stratigraphic architecture of a transtensional continental basin in low-latitude semiarid conditions: 
the permian succession of the central Orobic basin. J. of Sedimen. Res., 86 (4): 408-429.

Bureau of Fisheries and Aquatic Resources (BFAR). 2015. In Turbulent Seas: The Status of Philippine Marine Fisheries. Coastal Resource Management Project, The Philippines. p. 378.

Cairns, J., Dahlberg, M., Kenneth L. Dickson, K., Smith, N. and Waller, W. 2009. The relationship of fresh-water protozoan communities to the MacArthur-Wilson equilibrium model. Am. Nat., 103: 933.

Campos, I., Aguado, D., Ferrer, J., Gil, L., Soto, J. and Vivancos, J. 2012. A voltammetric electronic tongue as tool for water quality monitoring in wastewater treatment plants. W. Res., 46(8): 2605-2614.

Canencia, M. and Walag, A. 2016. Physico-chemical parameters and macrobenthic invertebrates of the intertidal zone of Gusa, Cagayan de Oro City, Philippines. Inter. J. of the Bioflux Soc., 8(1): 71- 82.

Carino, V.C., Casway, A.A. and Rivero, H.I. 1993. Use of Mollusks (Gastropoda and Bivalves) as a Biological Indicator of $\mathrm{Cu}$ and $\mathrm{Zn}$ Pollution in the Estuaries of a Mining Town in Camarines Norte(Philippines). Proceeding of the Second National Malacological Convention, Laguna, the Philippines, pp. 93-100.

Catteau, A. Bado-Nilles, A., Beaudouin, R., Tebby, C., Joachim, S., Palluel, O., Turiès, C., Chrétien, N. and Nott, K. 2021. Water quality of the Meuse watershed: assessment using a multi-biomarker approach with caged three-spined stickleback (Gasterosteus aculeatus L.). Ecotoxicol. Environ. Saf., 208: 111-207.

Chang, K.H., Amano, A, Miller, T. W., Isobe, T., Maneja, R., Siringan, F.P., Imai, H. and Nakano, S. 2009. Pollution study in Manila Bay: Eutrophication and its impact on plankton community. Inter. Stud. Environ. Chem. Res., 51: 261-267.

Deben, S., Aboal, J.R., Carballeira, A., Cesa, M., Real, C. and Fernandez, J.A. 2015. Inland water quality monitoring with native bryophytes: A methodological review. Ecol. Indic., 53: 115e124.

DENR Administrative Order No. 2016-26. 2016. Guidelines for the implementation of the coastal and marine ecosystem management program (CMEMP). Retrieved January 12, 2020 from https://server2. denr.gov.ph/uploads/r md d/d ao -2016-26.pdf

DENR 2013. DENR administrative order no. 2013-22. Supreme court e-library, 24 -No. 4. Retrieved August 16, 2021 from https://elibrary. judiciary.gov.ph/thebookshelf/showdocs/10/67621

DPWH 2004. Flood control project implementation system for principal rivers in the Philippines. Retrieved August 15, 2021 from https://www. scribd.com/document/470675949/Study-on-Flood-Control-Project-forRivers-in-the-Philippines.

Environmental Management Bureau (EMB). 2013. List of classified water bodies as of 2013. Retrieved October 23, 2019 from http:// www.emb.gov.ph/portal/Portals/24/Classified\%20Waterbodies/2013/ Classified\%20 WB\% 20201Region \%204a.pdf.

Fajardo, L. and Ocampo, P. 2018. Inhibition of acetylcholinesterase activities in whitegoby, Glossogobius giuris from the East Bay of Laguna Lake, Philippines. Inter. J. Agric. Tech., 14(7): 1181-1192.

Fierro, P., Bertrán, C., Mercado, M., Peña-Cortés, F., Tapia, J., Hauenstein, E., Caputo, L. and Vargas-Chacoff, L. 2015. Landscape composition as a determinant of diversity and functional feeding groups of aquatic macroinvertebrates in southern rivers of the Araucanía, Chile. Lat. Amer. J. Aqua. Res., 43: 186-200.

Fu-Liu, X. and Shu, T. 2000. On the study of ecosystem health: State of the art. J. Envi. Sci., 12: 33-38.

García-Seoane, R., Fernandez, J.A., Villares, R. and Aboal, J.R. 2018. Use of macroalgae to biomonitor pollutants in coastal waters: Optimization of the methodology. Ecol. Indic., 84, 710e726.

Gorme, J.B., Maniquiz, M.C., Song, P. and Kim, L.H. 2010. The water quality of the Pasig River in the City of Manila, Philippines: Current status, management, and future recovery. Environ. Engr. Res., 15(3): 173-179.

Hallare, A.V., Ocampo, K.A., Tayo, P. K. and Balolong, M. 2016. Genotoxic stress-induced by intensive aquaculture activities in Taal Lake, the Philippines on circulating fish erythrocytes using the comet assay and micronucleus test. Adv. Environ. Bio., 10(1): 273-283.

Herman, M. and Nejadhashemi. A. 2015. A review of macroinvertebrateand fish-based stream health índices. Ecohydrol. Hydrobiol., 15: 53-67.

Hughes, T., Baird, H., Bellwood, D., Card, M. and Connolly, S. 2004. Climate change, human impacts, and the resilience of coral reefs. Science, 301(5635): 929-933.

Ippolito, G., Petersena, E., Wilsonb, M., McCloskeyd, B., Mwabae, P. and Batese, M. 2016. Rapid spread of zika virus in the Americas implications for public health preparedness for mass gatherings at the 2016 Brazil Olympic games. Inter. J. of Infec. Dis., 44, 11-15.

Jan, A.T., Azam, M., Siddiqui, K., Ali, A., Choi, I. and Haq, Q.M. 2015. Heavy metals and human health: Mechanistic insight into toxicity and counter defense system of antioxidants. Int. J. Mol. Sci., 16(12): 29592-29630.

Jin, L. 2017. Cadmium Biomonitoring Summary. Centers for Disease Control Prevention. CAS No. 7440-43-9

Liang, C., Willey, J., Pollock, T., Thomson, E. and Walker, M. 2021. Exposure load: Using biomonitoring data to quantify multi-chemical exposure burden in a population. Inter. J. of Hyg. and Environ. Hlth., 34: 113-204.

Li L., Zheng B. and Liu L. 2010. Biomonitoring and bioindicators used for river ecosystems: Definitions, approaches, and trends. Procedia Environ. Sci., 2: 1510-1524.

Li, C., Pulin, Z., Wei, L., Wei, D., Jia, O. and Chang, C.C. 2018. Molecular biological methods in environmental engineering. Water Environ. Res., 90: 1371-1391.

Maagad, L. 2012. Benthic Macroinvertebrates and Water Quality of Iligan River. (Unpublished master's thesis). Mindanao State University-Iligan Institute of Technology, Iligan City, Philippines

Marrone, R. 2016. Water Pollution in the Philippines: Causes and Solutions. BORGEN. Retrieved November 6, 2020 from http://www. borgenmagazine.com/water-pollution-in-the-philippines.

Marzin, A., Archaimbault, V., Belliard, J., Chauvin, C., Delmas, F. and Pont, D. 2012. Ecological assessment of running waters: Do macrophytes, macroinvertebrates, diatoms, and fish show similar responses to human pressures? Ecol. Indic., 23: 56-65.

Mehana, E.E., Khafaga, A.F., Elblehi, S.S., Abd El-Hack, M.E., Naiel, M.A. and Bin-Jumah, M. 2020. Biomonitoring of heavy metal pollution using acanthocephalans parasite in the ecosystem: An updated overview. Animals, 10: 811.

Olivares, R., Sta Maria, E. and Sombrito, E. 2019. Environmental assessment of metal pollution in Manila Bay surface sediments. Phil. J. Sci., 149(S1): 183-195.

Pielou, E.C. 1998. Fresh Water. The University of Chicago Press, Chicago \& London.

Paulaa, D. and Andow, D. 2016. Uptake and bioaccumulation of Cry toxins by an aphidophagous predator. Environ. Poll., 209: 164-168.

Peligro, V. and Jumawan, J. 2015. Aquatic macroinvertebrates diversity and riparian channel and environmental inventory in Gibong River, Philippines. J. Ento. Zool. Stud., 3(5): 398-405.

PEMSEA. 2006. Sustainable Development and Management of Manila Bay: A Focus on Water Quality. PEMSEA, Quezon City, pp. 1-5

Presidential Decree No. 600. 1974. Prevention and control of marine pollution. Retrieved November 15, 2019 from http://www. coastguard.ov.ph/images/philcoastguard/PresidentialDecree/PD600. pdf

Presidential Decree No. 984. 1976. Providing for the revision of Republic Act No. 3931, commonly known as the pollution control law, and for other purposes. Retrieved January 28, 2020 from http://r12.emb.gov. $\mathrm{ph} /$ wp-content/uploads/2016/04/presidential-decree-no984.pdf

Presidential Decree No. 1067. 1976. A decree instituting a water code, thereby revising and consolidating the laws governing the ownership, 
appropriation, utilization, exploitation, development, conservation, and protection of water resources. Retrieved December 16, 2020 from https://www.lawphil.net/statutes/presdecs/p d1976/ pd_1067_1976.html

Rachon, D. 2016. Endocrine-disrupting chemicals (EDCs) and female cancer: Informing the patients. Rev. Endoc. Meta. Dis., 16: 359-364.

Ralph, P., Smith, R., Macinnis-Ng, C. and Seery, C. 2007. Use of fluorescence-based ecotoxicological bioassays in monitoring toxicants and pollution in aquatic systems: Review. Toxicol. Environ. Chem., 89(4): 589-607.

Reboa, A., Mandich, A., Cutroneo, L., Carbone, C., Malatesta, A. and Capello, M. 2019. Baseline evaluation of metal contamination in teleost fishes of the Gulf of Tigullio (north-western Italy): Histopathology and chemical analysis. Mar. Pol. Bul., 141: 16-23.

Republic Act 9275. 2004. An act providing for comprehensive water quality management and other purposes. https://emb.gov.ph/wp-content/ uploads/2015/09/RA-9275.pdf

Roohi-Shalmaee, N., Mousavi-Nadushan, R., Mostafavi, P., Shahbazzadeh, D. and Bagheri , K. 2019. Ecological adaptation of the Persian Gulf polychaete in a polluted area: proteomics concerning dominant defensive biomarkers. Inter. J. of Environ. Sci. and Tech., 17: 19371946.

Sia Su, G., Ramos, G. and Barcelon, E. 2015. Lead bioaccumulation and the imposex effect of Volema (Pugilina) cochlidium in Bacoor Bay, Philippines. J. of Fish. Sci., 9(3):001-004.

Siddig, A.A., Ellison, A.M., Ochs, A., Villar-Leeman, C. and Lau, M.K. 2016. How do ecologists select and use indicator species to monitor ecological change? Insights from 14 years of publication in ecological indicators. Ecol. Indic., 60: 223-230.

Sinco, A., Sendaydiego, J., Saab, L., Mojica, G., Tampus, G. and Rondez, A. 2014. Riverine biota as indicators of water quality in tropical Cagayan de Oro River, Philippines. Int. J. of the Bioflux Society, 6(2): 23-35

Superada, J. and Tampus, A. 2015. Macroinvertebrates as Indicators of
Water Quality in Three Estuary Sites in Iligan City, Philippines. J. Multidiscip. Stud., 4: 85.

Tellez, M. and Merchant, M. 2015. Biomonitoring heavy metal pollution using an aquatic apex predator, the American alligator, and its parasites. PloS One, 10: e0142522.

Tuddao, V. and Gonzales, E. 2016. Updates on Water Environment Management in the Philippines. Retrieved August 15, 2021 from http://wepa-db.net/activities/2016/20161130/PDF/11\%20Philip pines_ Country $\% 20$ updates_FINAL\%20PHILIPPINE\%20REPORT $\% 20$ Updates\%20on\%20Water\%20Environ ment \%20Management $\% 20$ FINAL\%20REVISED.pdf

UNDESAPD (United Nations, Department of Economic and Social Affairs, Population Division). 2018. World urbanization prospects: The 2018 revision, 2020-9-21. Retrieved August 15, 2021 from http:// creativecommons.org/licenses/by/3.0/igo/ (2018)

Vellinger, D. 2016. Lead contamination in flint-An abject failure to protect public health. N. Engl. J. Med., 374:1101-1103.

Vestil, J. and Lim, C. 2016. Special Report: Heavy Metals and More. SunStar Philippines, Cebu City, The Phillippines, pp. 1.4.

Walag, A., Canencia, O. and Fiedler, B. 2018. Water quality: Mindanao Island of the Philippines. Translating National Policy to Improve Environmental Conditions Impacting Public Health Through Community Planning, pp. 219-253.

White, P. 2012. Oil Spill Preparedness and Response for Mariculture Parks in the Philippines - AquaPark Working Report, Akvaplan-Niva, BFAR, pp. 1-28

World Atlas. 2020. Maps of the Philippines. Retrieved August 15, 2021 from https://www.worldatlas.com/maps/philippines

Zhang, Z. and He, L. 2010. Two new species of Pyemotes closely related to $P$. tritici (Acari: Pyemotidae). Zootaxa, 2723: 1-40.

Zhou, Q. and Jiang, G. 2006. Butyltin accumulation in freshwater clam Mya arenaria: An evaluation of its suitability for monitoring butyltin pollution. Chemosphere, 63: 1-8. 